\title{
Readiness and the International Medical Society of Paraplegia: The Sir Ludwig Guttmann Lecture 1984*
}

\author{
G. M. Pool, M.D.; ${ }^{1}$ and Albert Tricot, M.D. ${ }^{2}$ \\ ${ }^{1}$ Essenweg, 35 Rotterdam 16, The Netherlands and ${ }^{2}$ Centre de Traumatologie \\ et de Readaptatsion, Hopital Universitaire Brugmann, 4 Place Van Gehuchten, \\ Brussels, Belgium.
}

Mr President, Members of Council and Members of the International Medical Society of Paraplegia, Ladies and Gentlemen.

Sir George Bedbrook, our retiring President kindly invited Dr Albert Tricot and myself to give this year's Ludwig Guttmann Lecture. It is largely devoted to the interesting history of the International Medical Society of Paraplegia and to sport for the spinal paralysed. This Society was founded in 1961 in Stoke Mandeville Hospital England on a suggestion of Dr Houssa of Brussels and some others, as a result of the successful establishment of the International Stoke Mandeville Games.

Currently, every year competitors from nearly all over the world join in this unique sporting event. The late Sir Ludwig Guttmann, who initiated sport for paraplegics must certainly have felt very proud of its success, but I know that he was also concerned about its further development.

In an Olympic year the games have come to be called 'The Paralympics' and this year they should have taken place in the U.S.A., the host country of the Olympics. Because of the history of the Society we decided to relate this Guttmann Lecture to the Games, so Albert Tricot and I joined together in an effort to provide a history of the Society and its links with the Games. Albert Tricot, as you know became the first Belgian President of the Society succeeding the first American President, Dr Herbert Talbot and Dr Tricot has a very long experience of the Games, over 30 years. His French is better than his English. We both speak Dutch, therefore, I will read this Lecture in the English language, which is of course the official language of the Society.

I am just speaking in the name of so many who have helped our Society become what it is, an accepted International Society of specialists caring for paraplegic patients. The title of the paper was borne out of thoughts on movement and

\footnotetext{
${ }^{\star}$ Read at the Scientific Meeting of the International Medical Society of Paraplegia, Denver, Colorado, U.S.A., June, 1984. 
posture and their influence on the brain, but also out of thoughts of coordination between movement and posture, especially concerning the paraplegic person and his protection in his environment.

We decided to concentrate on the problem of reflex reactions, some of which have a protective function; and on the important role that they probably play in helping the patient to reach a (new) balance between his disturbed movement and his posture (Fig. 1), in his book 'The co-ordination and regulation of movements', the Russian physiologist Bernstein (1967) stated that tone is a condition of readiness brought about by experience and effect and not just a condition of elasticity of muscles alone. Tone in the sense of readiness develops gradually. The development of motor behaviour already begins in the prenatal period and continues in infancy. It starts with total body reactions which gradually train the brain to react to rapidly changing situations, such as those encountered in sport.

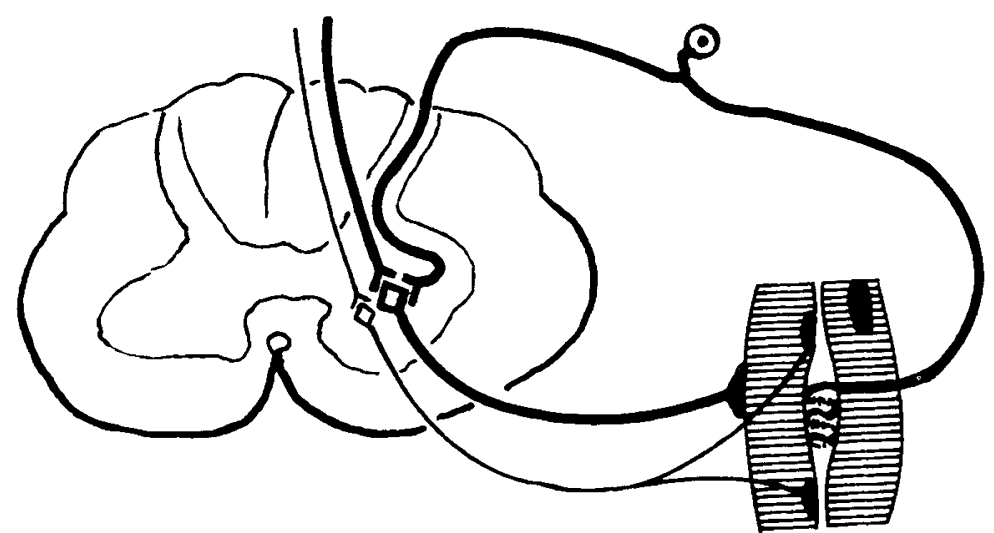

Figure 1. Diagram of the dual innervation of muscle. The efferent innervation of posture occurs through the small diameter fibres. The spindle afferent discharge occurs through the thick fibres as does movement activity.

In the last chapter of his book Sir Ludwig Guttmann (1973), deals with the essence of rehabilitation and states that in severely physically handicapped people such as spinal paraplegics and tetraplegics the essence must lie in restoring activity of the mind!

\section{Development of normal motor-behaviour}

According to Jacobs (1967), Humphrey and Hooker observed that human motor behaviour commences before birth at about the middle of the 7 th week of gestation, when the embryo has reached a length of $20 \mathrm{~mm}$. The first movement that appears after stimulation of the perioral region is a lateral bending of the head. The receptive field for stimulation gradually matures and spreads caudally from the face to the shoulder and the palm of the hand and later to the lower extremities. Movement as a result of stimulation of the skin develops in the shoulder-hand region at 10.5 weeks. Whether or not hand-mouth 
contact occurs in utero has not been observed, but the relation is clear and strong after birth. Foot and leg movements due to stimulation start at about the 11 th to the 12th weeks. By 18.5 weeks grasp of the fingers develops and by 25 weeks the thumb participates actively in this movement. Early reflexes in foetal life elicited by tactile stimulation, take the form of total pattern responses and seem to remove the foetus from the source of stimulation, they develop from head to tail. After birth this process continues: initially the arms alone are responsible for locomotion, which at first is crawling, but as the upright position is assumed supporting reactions appear in the extended lower extremities. Thus participation of the upper limbs in locomotion is well in advance of that of the lower extremities. One may assume that reflex activity in foetal life and early infancy form the fundamentals of voluntary motor actions later on.

\section{Disturbed motor-behaviour}

There are many causes of disturbances in motor behaviour and many different patterns exist, and we can divide these in several ways, for example:

a Congenital and acquired.

b Central and peripheral.

c With or without brain-damage, and certainly many other possibilities for a classification exist. For the purpose of this paper however we prefer a division into.

(1) Disturbances of the pre-Guttmann period, and (2) the period he initiated and which we do not call the post-Guttmann period, because happily there is no way back. However, there is a borderline-the Second World War. Before that War, according to Cosbie Ross and Phillip Harris (1980) in their tribute to Sir Ludwig Guttmann, 'An injury to the spinal cord was virtually a death sentence'. 'Those who have started working in paraplegia during the last 15 or 20 years have entered a field of promise', they stated. One can observe the changing face of rehabilitation in the work of Sharrard (1957). He found by counting the number of motor nerve cells, that with more than 40 per cent a muscle will act with power, clinically indistinguishable from normal, and that with as few as two per cent of motor nerve cells, a muscle will show a detractable contraction. Apparently, there are a large number of motor cells in reserve. The poliomyelitis problem has been successfully solved with the Salk-vaccine and is but rarely seen in Western Countries at present. Sharrard devised new possibilities of attacking the problem of paraplegia in 1963 when he reported advances in the management of myelomeningocele and hydrocephalus for the International Medical Society of Paraplegia at a Meeting in Stoke Mandeville Hospital. Immediate surgery appeared to show less mortality and less paralysis, although many of these children would remain crippled. In the discussion of that paper someone remarked: 'What are we doing for these patients?' A question which was answered 8 years later by Lorber (1971). He showed that there was a borderline on the basis of his 12 years experience. Lorber gave evidence that selection for treatment can be made on the first day after birth and that such an approach is appreciated by the parents. In the same number of 'Paraplegia' in which Sharrard's paper was published, Bedbrook 
(1963) made some pertinent observations on the pathology of traumatic spinal paralysis. He stated that surgery must be undertaken with a firm knowledge of basic pathology and that operative interference does not always confer benefit. In 1966 Bedbrook dealt with pathological principles in the management of spinal cord trauma, and I quote 'Adequate clinical judgement in medicine needs physicians who have knowledge of morbid pathology. Morbid physiology and human understanding.' Bedbrook pays much attention to the pattern of the spinal cord arteries and their relation to pathological features (1981). In the treatment of paralysis there has been a change from the reflex diminished poliomyelitis victim to the reflex excited patient, who is frequently a victim of a traumatic lesion. The lonely role of the orthopaedic surgeon in the past has been taken over by a whole range of specialists.

Besides surgery many inventions and developments have been discovered to help the paralysed patient to adapt to his new situation. However, not all such patients can cope. In 1972 Kerr and Thomson published a survey of 181 patients with acute paraplegia, and came to the conclusion that the process of mental adjustment is a gradual one. They stressed that the major factors for good mental adjustment are the patient's age, his previous mental health and the family background, and concluded that the adjustment process takes 2 years at least to complete and that this can best be achieved in the atmosphere of a small unit, where there are patients with similar disabilities and problems and where the morale must be high.

\section{Protection and co-ordination}

Most spinal cord paralysis sufferers have in common at least weakness of their legs, but vary in the degree of spinal cord involvement concerning posture, movement and reflexes. The age and memory of each individual sufferer and the circumstances in which he became handicapped are not the same. Moreover patients do react in different ways to the paralysed situation. Once the patient has become paralysed, he must come to grips with the fact that he will remain to some extent dependent on others, whether they are members of his family, the social authorities or the medical staff. He must also learn to adapt to different types of equipment, to be driven around in a wheelchair, to eat his food and to get in and out of bed. The earliest experience with paralysed people was with poliomyelitis victims. Before the Salk-vaccine became available even paralysis of the intercostal muscles was treated by way of an artificial breathing apparatus, and if sufficient restoration of breathing did not develop there was sometimes the possibility of so called 'frog breathing'. In that way, patients became independent of respirators, which was possible because of complete paralysis of posture and movement reflexes (Pool and van Weerden, 1973).

The poliomyelitis toxin left the brain undamaged and sensation intact. Thus victims were even able to carry out such important functions, as President of the United States. The spinal column does not protect the cord against disease but to some extent protects against injury due to its strong and elastic structure. Reflex action is thus well protected within the column, and in reverse the column is protected by reflexes against injury, for example, during a sudden 
fall both arms are, reflexly elevated to intercept and receive the impact so that the head is protected from the approaching object.

Reflex leg movements do protect the body during a fall when in the upright position and reflex flexion of one leg will automatically stabilise the other.

I know that Sir Ludwig was interested in reflexes, and indeed, in the first number of Paraplegia he published together with Munro, Robinson and Jack Walsh a paper on a reflex subject (1963). They reported the effects of rapid postural changes in paraplegic patients on a tilting table. To measure reflex actions is an old problem; flexion reflex actions were the first to reveal the problem of muscle tone, which is closely linked with the problem of co-ordination, but are impossible to measure (Pool, 1971). The flexion reflex was elicited by moving a dangerous stimulus. In some patients with a complete cervical lesion the movement and postural aspects of reflex action were found to be separate, a pattern that was also recognised by Rossier for bladder action in the upper motor neurone type of neuropathic bladder (Pool, 1965). In the last chapter of his book on 'Comprehensive management' Sir Ludwig summarises spinal reflex actions as follows: 'The accomplishment of the spinal man's physiological integration lies in the restoration of a co-ordinated function between the isolated cord and the remaining components of the nervous system'. In 1944, very soon after the establishment of the Stoke Mandeville Spinal Injuries Centre, Guttmann introduced sporting activities as an essential part of medical treatment, to overcome reflex incapability. This proved most essential for the physical readjustment of patients and it paved the way to a more enjoyable life. Frankel (1976) in his review of Sir Ludwig's textbook for the disabled, added to this by saying that sport is a most important means of social re-integration. The International Medical Society of Paraplegia was founded thanks to the stimulating effects of the International Stoke Mandeville Games!

A short film of reflex protection will show you how both arms protect the body and at the same time protect the head during a sudden fall. The film (which was shown during this Lecture) was made with a high speed camera, capable of $600-800$ exposures per second. It was noted that in 'slow motion' the reflex action of both arms resembles the reflex of Moro, which is normally seen in babies a few weeks following birth.

\section{Stoke Mandeville Hospital and the Paralmypics: some facts and dates (Dr Albert Tricot)}

Providing some historical facts about the International Stoke Mandeville Games, my story starts in 1947 , very precisely on the 25 th January of that year.

\section{7}

'Thanks Hitler'; such was the title of an article published in the 'Eastbourne Chronicle' in England. Five lines were devoted to the activity of a Spinal Unit of the Ministry of Pension Hospital at Stoke Mandeville. Dr Guttmann who had fled from Silesia in 1942 because of anti-semitic measures, had been 
appointed director of this new Unit and was wholly involved with the treatment of World War II paraplegics.

Ludwig Guttmann a dedicated and practising sportsman, especially in fencing, appreciated the qualities of sport which develop courage, emulation, and the greater excellence of oneself. Knowing the destitute moral condition of paraplegics, he had the idea of utilising sport as one important means of physical therapy. First there were games or rhythmical gymnastics, such as wheelchair polo or Indian club swinging. When Guttmann had an idea nothing could stop him, thus having given archery and wheelchair net-ball the status of therapeutic disciplines, he decided to organize the first sports festival for handicapped people.

\section{8}

He also announced his far-flung intentions as he chose the day of the opening of the Olympic Games in London on the 29th July, 1948, to organize the first sports festival for the paralysed at Stoke Mandeville Hospital.

\section{2}

However, this sports festival had to wait until its 5 th occasion, on the 26 th of July, 1952, to become international. The International Stoke Mandeville Games were born thanks to the participation of a team of paralysed ex-service men from a specialised hospital in the Netherlands.

In 1953, Canada, Finland, France, Israël and the Netherlands were represented at the Stoke Mandeville Games for Paraplegics.

\section{4}

In 1954, 14 nations participated in the third International Stoke Mandeville Paraplegic Games. Amongst them was the first Belgian delegation which I am now presenting to you, because it had a symbolic European character, starring two Belgian Nationals, a French girl and an Italian boy. Such was the first Belgian archery team.

Please excuse me for referring so often to my country but the story of the Stoke Mandeville Paraplegic Games is also that of a very rewarding part of my life. This was the first time that I was involved in the dynamic and even intoxicating atmosphere of the Stoke Mandeville Games. Guttmann proclaimed his enthusiasm and his faith under the banner of the Games: 'The aim of the Stoke Mandeville Games is to unite paralysed men and women from all parts of the world in an international sports movement, and your spirit of true sportsmanship today will give hope and inspiration to thousands of paralysed people. No greater contribution can be made to society by the paralysed than to help, through the medium of sport, to further friendship and understanding amongst nations'.

The movement was launched. Faith in the future of sports for handicapped people rapidly overflowed from the Stoke Mandeville region, and other nations 


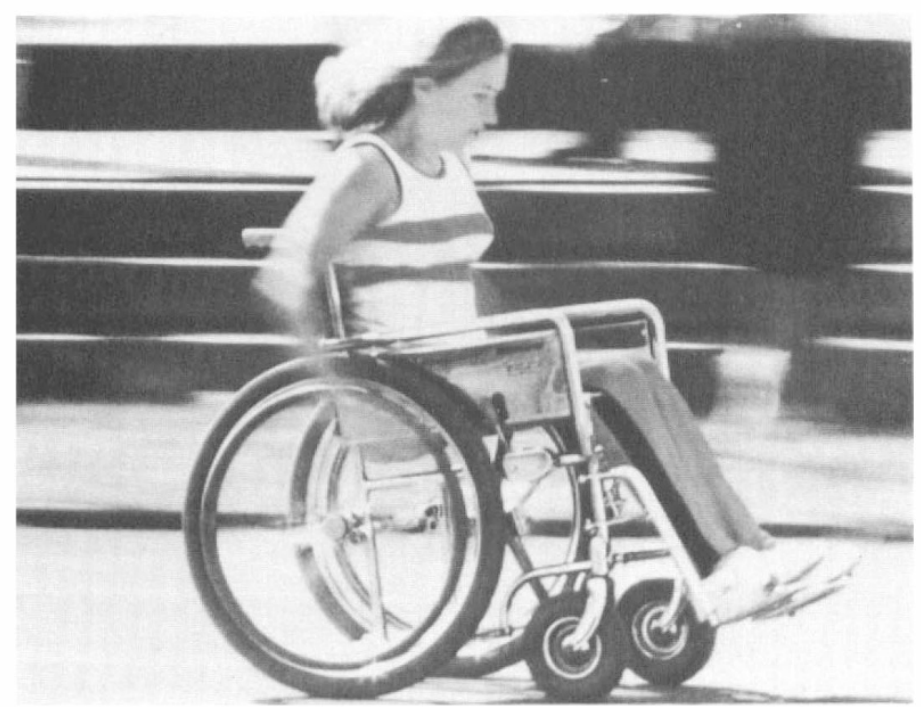

Figure 2. Wheelchair-race.

of the world started step by step, as far as they were able to become personally involved with this great annual sportive assembly.

Fencing, Guttmann's favourite sport completed the annual sports events. Archery was improving, as was shooting, using special wheelchairs. We were probably the first to present a wheelchair specially adapted for archery, and in this particular case also adapted to the handicap of our champion archers.

Up to this time the Games had always been held on the lawn in front of Stoke Mandeville Hospital in Aylesbury, Bucks, England. The developments taken up by the technical organization, and also the increasing number of participants necessitated a move to larger and better facilities. Indeed, it was necessary to move far away, because Guttmann acquired the necessary subsidies to refurbish some old buildings, the 'huts' of the British Army. He even found means to acquire some new ones. Roger Bannister recent Olympic mile champion came to salute the handicapped athletes shortly after his victory. The closing march past of paraplegic athletes took on a more solemn air. Let us salute the representative of Australia and the first United States team, sponsored by Pan Am.

\section{7}

Very quickly the infrastructure became too small because Guttmann was always aiming higher and higher each year. We soon saw on the lawns of StokeMandeville, the famous 'Marquees', with the flags of participating countries flying in the wind, whilst the archers were improving their marks.

On the European continent, the first international competitions were organized in Brussels. Her Majesty Queen Elizabeth of Belgium welcomed by a 
handicapped athlete, presided over the inaugural ceremony in the presence of a French team, and the first British Team to come to the Continent, also the first Italian team with its leader, our friend Dr Antonio Maglio.

Here is a souvenir of the first basket-ball match fought between the British and Belgian teams in Brussels. (This was shown to the audience by $\mathrm{Dr}$ Tricot). The prize giving ceremony was held in the presence of the Little Black Singers and of the President of the Belgian Olympic Committee.

1960

Guttmann inaugurated his first sports festival at Stoke Mandeville on the day of the opening of the Olympic Games in London. He had pursued his dream and made it come true in collaboration with Antonio Maglio by organizing the 9th International Stoke Mandeville Games in Rome on the occasion of the Olympic Games immediately after the closure of these. The handicapped athletes in the wheelchairs filed past in the Olympic Stadium in Rome. The paraplegic athletes were accommodated in the Olympic Village and certainly required their sports escorts because of the many steps of the buildings. The event was a great success and a very solemn one. At the same time, it was a big step forward for the Olympic movement for handicapped sportsmen and sportswomen.

1961

Up till the 1960 Games had been the occasion for inviting the escorting specially involved doctors to an Annual Scientific Meeting which was held in the Gymnasium in Stoke Mandeville Hospital, where the chairs were a sure guarantee against any sleepiness! It was time to make the 'Scientific Meetings' official. This was done on the 28th July, 1961, when the International Medical Society of Paraplegia was founded.

The Founder Members included are: W. Arens, J. Benassy, A. Brugger, J. Cosbie Ross, Dr Damanski, P. Dollfus, H. L. Frankel, T. Gregg, A. Grossiord, L. Guttmann, D. O. Hancock, P. Harris, P. Houssa, A. Jousse, Dr LambertiBocconi, A. Lob, A. Maglio, M. Maury, I. McKechnie, J. Melzak, L. Michaelis, J. Midedema, B. Audic, A. Palcinelli, M. Schillings, H. Talbot, D. Thomas, G. Ungar, J. Van der Maas, S. Varma, E. Wadge.

The subscription was of 5 Guineas ( $£ 5$ and 5 shillings-'old value'), for ordinary members and of 2 Guineas ( $£ 2$ and 2 shillings-'old value'), for associate members.

1964

Some important stages in the development of the Games occurred in the following years. I will pick out the most important ones, to begin with, Tokyo in 1964. The Paralympics were opened by the Crown Prince and the Princess. The handicapped athletes were welcomed in oriental fashion with warmth and kindness, and they returned with moving memories.

For the first time, Federal Officials helped with the organisation of the 
Olympics for handicapped. This is the occasion to present an old Italian friend Marsan throwing the discus, and also a splendid American athlete throwing the javelin, who helped to develop the Games. But let us return for a while to Stoke Mandeville. There was sunshine, and it can be suspected that Ludwig Guttmann had made a pact with the Sun because it was rare for the Stoke Mandeville Games not to benefit from nice weather, the more so as the preceding weeks had received their usual share of the typical British downpour. The closing ceremony was held in front of the celebrated huts, and amongst the spectators was Pierre Houssa, an English carnation in his button-hole, on the occasion of the 13th Belgian participation in these Games in 1965.

\section{6}

But Guttmann went on dreaming or more precisely went on imagining ways to make all of his dreams come true. One of his schemes in the year 1966 was the construction of a National Stadium specially built for the paralysed and other physically disabled persons. Large plots of land, behind Stoke Mandeville Hospital, lent themselves readily to this project. Some consultations, and some pretty persuasive conversations, and with the help of his many friends and of the whole population of Stoke Mandeville and of Aylesbury, and with financial support also coming from outside and especially from the Netherlands, occurred, and soon work was under way.

1968

The Games were held in Tel Aviv in 1968, so that the architects, the contractors, and especially Ludwig Guttmann had sufficient time to plan a superb sports complex, unique in the world. The Rome Games had attracted 400 participants, Tokyo 700, and Tel Aviv 750-representing 29 nations. The march past in the twilight in the Jerusalem Stadium will remain one of the most moving memories that I have in the sports field. Israel was celebrating the 20th anniversary of its foundation, and was welcoming not only one of its sons, Ludwig Guttmann, but also the entire world. We had 12 enthusiastic days in that sunny land, even in November, and there were many regrets at the time of parting.

\section{9}

However, the regrets faded when, on the 2nd August 1969, Queen Elizabeth of Britain inaugurated the Stoke Mandeville Sports Stadium for the paralysed and other disabled. She was greeted by Jimmy Laird, the sculptor of the statuette which welcomes all visitors at the doors of the Sports Stadium. This complex was not only sportive but constituted a marked improvement in the accommodation for the participants and their escorts. The restaurant seating for 250 completed this superb realisation.

And so the years passed. Ludwig Guttmann did not show in public the pain that he endured when on the 25 March 1972, his wife had a terrible accident and became very ill. His will always reflected his desire to make the Games bigger and more beautiful and more 'Olympic'. 
1972

There were 1000 participants in Heidelberg, West Germany. The organisation was perfect. The organisation and facilities had also improved, especially for the wheelchair races. Forty-three countries were represented at these Games.

Lady Guttmann died just after Christmas on December 271973.

1974

Sport is emulation. There was emulation also in the organisation of sport at international level as well as at national level. The first European Championship for archery was held in Brussels in the majestic National Stadium.

Concomitantly, sports activities practised by the paralysed and by amputees were developing principally in athletics. Discus, javelin and club throwing, putting the shot, races, jumping and swimming took their place in the international competitions due to the interest and enthusiasm of the International Sports Organisation for the Disabled and of the I.S.M.G.F.

The ladies considerably improved their scores. At the same time, technical research was developing in view of the improving performance in racing (Fig. 2).

1976

The Olympic ideal was further strengthened on the occasion of the Montreal games. Toronto in Canada proved its ableness for organisation by inviting 1600 athletes 'A time to be together'. For the first time, the paralysed, amputees and blind athletes as well as those with cerebral palsy were drawn together. One remarkable feat during these games was the fantastic high jump of a femoral amputee, Harry Boldt, who jumped $1.86 \mathrm{~m}$. The memory of this achievement will never perish in the minds of those who beheld it. Thanks again to our Canadian friends who met this wonderful challenge. Guttmann, President both of the I.S.M.G.F. and of the I.S.O.D. was happy. This man of spirit, on which years were passing without leaving any obvious trace, seemed even less tired at the end of the Canadian Games in Toronto. Farewell Toronto, Farewell Canada!

Already our Dutch friends were actively preparing Arnhem and its Paralympic Games.

1980

Princess Margaret presided at the Opening Ceremony of the Arnhem Games, the organisation of which was impeccable. Unhappily the weather was not good, typically Dutch in fact, but Ludwig Guttmann had left us on the 18 March 1980. He had departed from his children, his athletes. But he left to us a monument in sports. A realisation which was his. It is with emotion that I look upon this last image with Ludwig Guttmann shortly before his death. It was a cordial handshake, the embrace of a father, of a sincere friend.

If technique was in full progress and if the racing wheelchairs had truly become 
special solids, medical control was being structured and developed, thus refining the classification examinations for disabled athletes.

Arnhem also beheld a special feat, that of the American weightlifter Brown, who beat the world record which he already held with $263 \mathrm{~kg}$. The closure of the Arnhem Games was a great festivity for sport, friendship and Olympics. Ludwig Guttmann was proud and happy of having realised his dream (Fig. 3). His book 'Textbook of Sport for the Disabled' has stimulated the extension of the sport movement for handicapped all over the world. His Olympic Village and his Stadium at Stoke Mandeville are symbols of his faith in an ideal and of his will to create. The I.S.M.G.F., I.S.O.D., I.B.S.A., and C.P.I.S.R.A. collaborate for the sport ideal and for the unification of the different types of events and of the different categories of handicapped athletes.

1982

The first Winter World Games for the Disabled were a renewed occasion to demonstrate the necessity for this collaboration. Spectators were able to admire the efforts and the willpower of ski-ing amputees, of the blind, and of paraplegics in ski bob. So, let us not forget the Olympic Ideal, the ideal of Guttmann; let us avoid that he should judge us from his immortal tribune.

1984

If he had still been with us, Ludwig would certainly have pointed an accusing finger at us (Fig. 4). The failure of the organisation of the 7 th World Wheel-

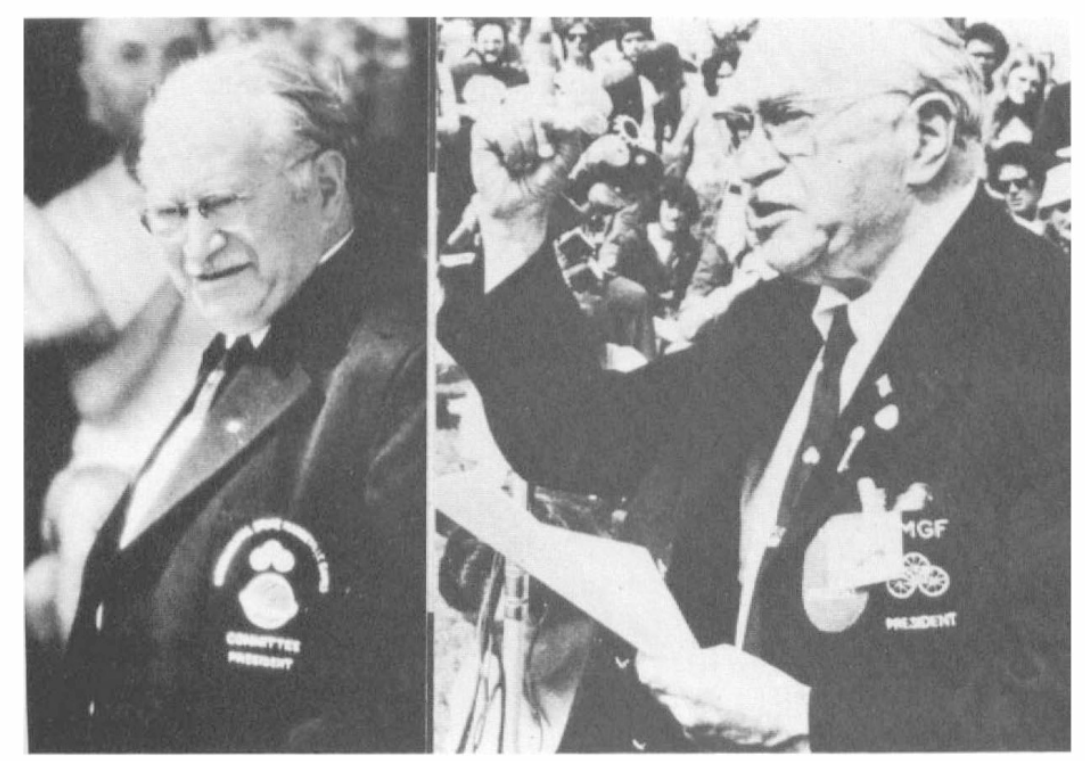

Figures 3 and 4. Sir Ludwig Guttmann, C.B.E., F.R.S. the initiator of sport for paraplegics and the founder of the International Medical Society of Paraplegia. 
chair Games was deeply felt by the athletes. I do not wish to look for responsibilities. I can only say that, after having worked at Sir Ludwig Guttmann's side for 30 years, if such a failure should repeat itself, this would be gravely instrumental in jeopardising a very important sport movement.

Friendship, Sportsmanship and Unity, is the Motto of the International Stoke Mandeville Games Federation; and was the Motto of Sir Ludwig Guttmann.

\section{Some thoughts about the history of the International Medical Society of Paraplegia (G. M. Pool)}

Readiness and the International Medical Society of Paraplegia was chosen as the title because it combines in some way the problems of movement and reactions which are so important for paraplegic persons and the problems of the Society in this rapidly changing world. The Society must be ready to meet and to adapt to the problems that it encounters.

In preparing this Lecture, I was very pleased to receive a letter from $\mathrm{Mr}$ James Cosbie Ross, one of the founder members of the Society. Since 1947 he has attended the meetings in Stoke Mandeville, because he was so impressed by what he saw of Ludwig Guttmann and his work. Since the Journal began he has been and continues to be Assistant Editor. At first the I.M.S.P. Meetings were held in the gymnasium of Stoke Mandeville Hospital and they united doctors interested in paraplegic problems under the leadership of Ludwig Guttmann. As Cosbie Ross writes, it is especially important at the present time to strengthen the I.M.S.P. and prevent fragmentation. It is very important too that National Committees concerning paraplegia and rehabilitation should remain closely linked with the International Medical Society of Paraplegia if real progress is to be continued. Readiness to co-operate, to co-ordinate and to protect what has been achieved until now for paraplegic persons is most essential. In those early days a number of excellent papers were read in the gymnasium and good discussions took place. A study of the items dealt with in the first 10 years of the Society showed that urological problems came foremost, and thus we saw Cosbie Ross several times sitting on the stage of the gymnasium, presiding over a session as Chairman in 1966 (Paraplegia 4:209-211). He read his historical paper on the diversion of urine in paraplegics, which ended with a plea for patience and for time to allow the spontaneous recovery of micturition.

\section{Organisation and classification}

A subject which attracted much attention in those first years was the organisation of spinal units. In 1967 papers were read from 15 different centres from all over the world. Ernest Bors on that occasion stated that (Paraplegia, 1967; 5:126-130), 'Most of all I had to learn patience to listen to rather than to force nature, to adjust rather than to attack; to observe deduce and not to try to play providence'. Amongst the specialities 'where the scalpel is used'. The pathologist was in the minority with presentations, but Lionel Wolman (Fig. 5) will be remembered for his excellent papers: 'The neuropathology of traumatic paraplegia' (1964), and 'Axon regeneration after spinal cord injury' (1966). Alan Hardy (1969) wrote in his memoriam on Dr Wolman, 


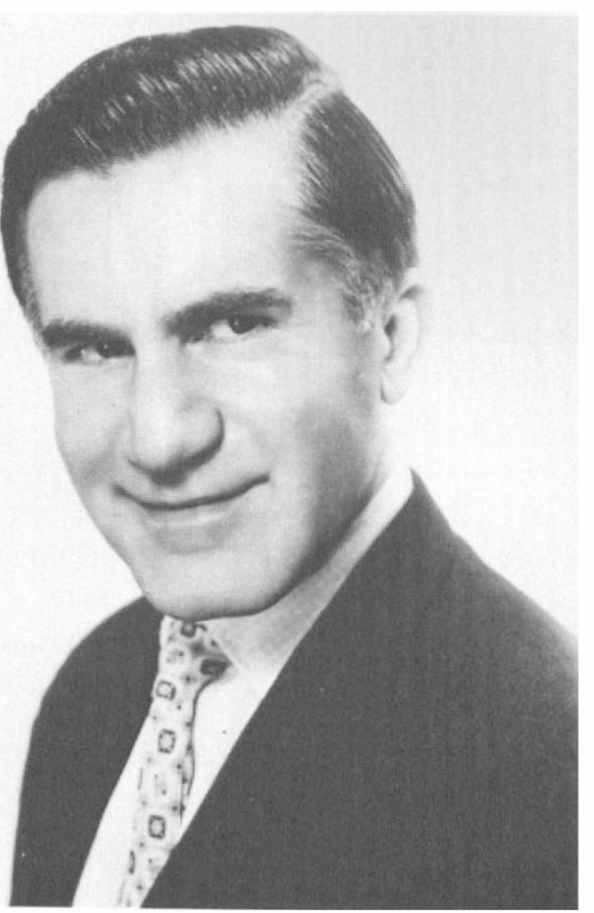

Figure 5. Dr Lional Wolman, M.A., Ph.D., M.D., F.R.C.P., F.C. Path., D.P.M.

in 1969: 'His sudden death has robbed neuropathology and the I.M.S.P. of one of its most loyal and interested members'. Wolman (1968) took part in the discussion on classification of neurological lesions, a subject for which there is 'No common market' according to Paul Dollfus (1970) and which took many hours of discussion after an international enquiry done by Michaelis (1969) with replies from 42 colleagues from 35 spinal units in 15 countries. After he had congratulated Michaelis on his hard work and hard thinking, Dr Wolman made a plea for the pathologist's point of view and recommended consideration of three factors:

1. The level of bony injury (if present).

2. The level of maximal cord damage.

3. The vertical extent of cord damage in both directions.

Many important doctors of that period took part in the discussion, including a young 'Paraplegist' from Australia, Dr Yeo (1967), who dared to remark that he was interested in the dogmatism that comes from many different specialities involved in paraplegia, and he also stressed the importance of pathological changes in the spinal cord, and the necessity for close co-operation with the neuropathologist. In a review on experimental research by Yeo (1976) Wolman's investigation and detailed findings at autopsy carried out on 76 paraplegics, 12 months to 32 years after injury: was an important contribution. In 12 of his patients Dr Wolman had found changes, although no 'Common Market' came out of that discussion on classification, it certainly clarified the shortcomings of the International World Health Classification. This was 
stressed by Dr John Young, and resulted in the very important research done in Phoenix, U.S.A. by Dr Young in collaboration with the National Spinal Cord Injury Data Research Center (1976; 1982). In almost his last editorial Sir Ludwig warmly congratulated John Young for having started this most important work, the results of which came out two years later (1982). It should be looked upon as a realistic answer to the problem of classification of spinal injuries, and of the rehabilitation answer to the work that was started 40 years ago in Stoke Mandeville Hospital. A complimentary answer to that problem appeared in 'Paraplegia' as an editorial by Dr Al Jousse from Toronto (1982); he wrote: 'It appears that in the first wave of exaltation over the achievement of having reversed the mortality in spinal cord injured persons, we may have forgotten that these individuals remain seriously disabled and greatly at risk from many dire threats to their wellbeing'. Jousse believes that ongoing encouragement and support by a trusted medical attendent is the most important contribution from doctors treating spinal paralysis patients once the early phase of rehabilitation has been completed. This is what Dr John Young has called 'The art of the specialty', and Sir George Bedbrook stated. the real challenge to those involved in the care of the spinal paralysed in his last newsletter to the International Medical Society of Paraplegia.

\section{The separation from the games}

In 1970 there were two meetings of the Society and two sporting encounters. The second meeting took place in Edinburgh immediately after the Stoke Mandeville Meeting. The Scientific Meeting in Edinburgh, Scotland coincided with the Commonwealth Paraplegic Games. I went to Edinburgh by train, and the moment after passing the Scottish Border two elderly people in my compartment remarked: 'Now we are home again, we are Scottish!!'. Passing the boundary had given them the feeling that they were home again, which is important. For many members it was the first time that they had attended a meeting of the Society outside Stoke Mandeville Hospital in 'a foreign country'. Edinburgh was a success and the reception in the Royal College of Surgeons a great event. The following year, we felt that we were home again in Stoke Mandeville Hospital, but realised that the links between the Games and the Society Meetings had become more tenuous and the interest of each more different. The separation between the two became a fact in 1979, when the Scientific Meeting took place in France, after the Stoke Mandeville Games. The Society had outgrown the small club of travellers of good will from all over the world, who in the beginning had been satisfied with the gymnasium and the local lodging in one of those wonderful local hotels near Stoke Mandeville, such as the 'Red Lion'. It had become an international body with many branches. A farewell party in the old gymnasium is still something to be organised, before the old memories have vanished! In his paper in Paraplegia, 1967, Sir Ludwig Guttmann describes the history of the International Spinal Injuries Centre, Stoke Mandeville. Then in 1979 in Paraplegia, Miss Joan Scruton published a paper in which she gave a very personal account of how Sir Ludwig created and developed the World Sports Movement for the paralysed and other disabled people. 


\section{Some thoughts about 'the post-Guttmann era'}

After the Meeting in Holland, the first meeting in which Sir Ludwig Guttmann was absent, many developments occurred; Phillip Harris, a Founder Member of the International Medical Society of Paraplegia, who had visited Stoke Mandeville Hospital every year since 1945, and who had introduced sport for the disabled in Scotland in 1963, accepted responsibility as Chief-Editor of Paraplegia. His first Editorial, 1980, ended with the sentence: 'Where there is no vision the people will perish', and vision was needed to keep abreast of new developments, and on the other hand cope with the problems of the rising costs of travel and of Membership of the Society.

Under the progressive leadership of the I.M.S.P. by Sir George Bedbrook from Perth in Australia, problems of National representation and reorganisation came under discussion. The experiences of Dr Nakamura from Japan and Dr John Young, from the U.S.A. played important roles in that discussion. Amongst the goals to be achieved by reorganisation Dr John Young mentioned:

1. Increased membership.

2. Better communication between leadership and members.

3. Reduction of the administrative load upon the central office in Stoke Mandeville Hospital.

4. Stimulation of educational activities within the regions.

It all started 40 years ago, on the first of February, 1944, as one of the medical preparations for the second front of World War II with the opening of a special unit for spinal cord injury sufferers. This had a world-wide effect and became a movement with Sir Ludwig Guttmann as the leader. After his death others took over: Frankel, Harris, Bedbrook with many others in support. At the present time it is very important to strengthen the Society and prevent fragmentation. We need new talents to keep the ship a-sail. In the first chapter of his book on the comprehensive management of the spinal paralysed, Sir Ludwig philosophises on the problem of talents and in an attempt to analyse the problem he wonders:

Is talent the prerogative of man? What role does experience and memory play?

What is the significance of learning?

It is not possible on this occasion to recall all of our missing talents, but in Wolman, Michaelis and Marian Weiss, we remember three of them, who represent them all.

Four hundred years ago Prince William of Orange, the leader of the Dutch Resistance against the Spanish King Philip the Second, was shot. His sons continued the religious and guerilla War, which lasted 80 years. During that period thousands of sailing ships from the most important trade centre of that time, Amsterdam, sailed around the world in search of new routes and new trade possibilities.

One of these ships (De Halve Maan) lost its way because of icebergs, and finely arrived at a fine rivermouth. Two years later a new settlement was built there, which got the name New-Amsterdam and was later renamed New York. Also, in that period a young painter settled in Amsterdam, and his first important commission became a famous painting: The Anatomy of Nicolaas Tulp; the name 


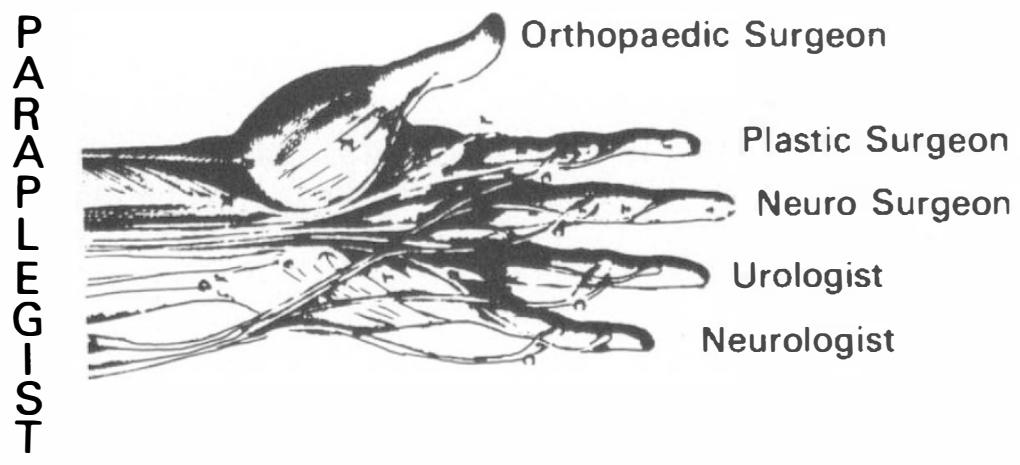

Figure 6. The hand drawn by Casserio (1627), which was probably copied by Rembrandt in his painting 'the anatomical lesson of Nicolaas Tulp' (1632). It illustrates the alliance between the surgeons and the paraplegist.

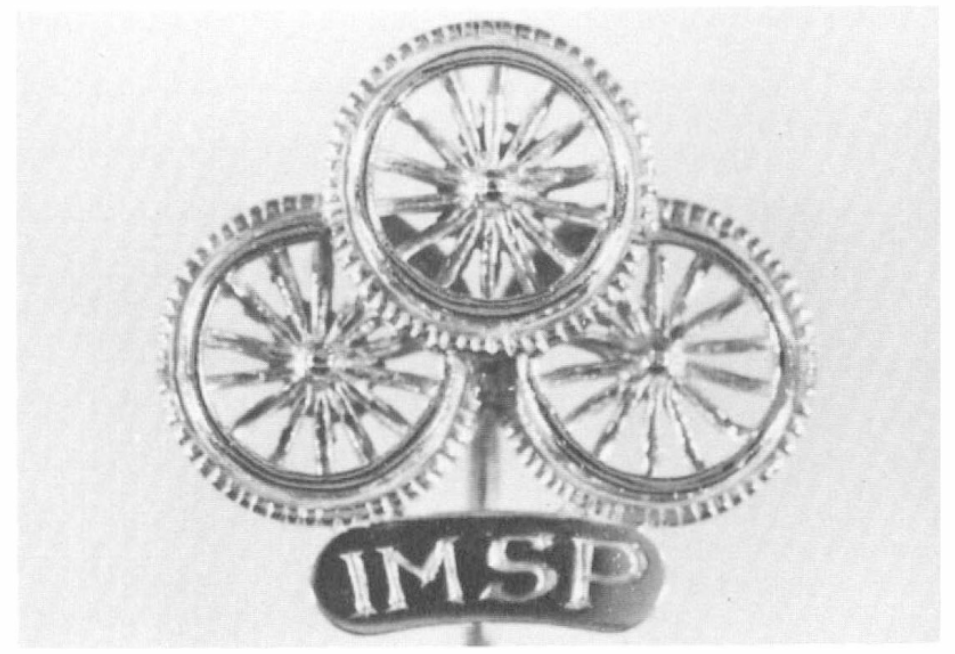

Figure 7. The badge, which was presented to the President of the I.M.S.P. Sir George Bedbrook and the President-Elect Alain B. Rossier after the Lecture, as a token of the alliance between the International Stoke Mandeville Games and the International Medical Society of Paraplegia. (Actual size: $20 \mathrm{~mm}$ ).

of the painter was Rembrandt Van Rijn. The demonstration Tulp is giving in the painting is that of the surgical secret, which was supposed to be the instrument that makes the fingers bent and co-ordinate (Fig. 6). There are many publications on the structure of the tendons of this painting, which was probably duplicated from the book in the foreground, which is supposed to be the 'Fabrica', with drawings from Casserio (Querido, 1983). The composition of the morphology and the function of the fingers are thought to be superior for that time. The painting was made to illustrate the alliance between surgeons, and in that way important too for our Society: The alliance between the various National Committees and the necessity to co-operate and make the International 
Medical Society of Paraplegia the body to which the fingers are attached. It also illustrates the most essential role that the 'Paraplegist' has in the coordination between the various disciplines.

Our Society is in need of a new generation of doctors to continue the work and the fight; which was started 40 years ago by Sir Ludwig Guttmann.

\section{Note}

A special badge was designed and was presented to Sir George Bedbrook and to Professor Alain Rossier to demonstrate the close link between the International Stoke Mandeville Games and the International Medical Society of Paraplegia (Fig. 7).

\section{References}

BEDBROOK GM 1963 Some pertinent observations on the pathology of traumatic spinal paralysis. Paraplegia 1:215-227.

BEDBROOK GM 1966 Pathological principles in the management of spinal cord trauma. Paraplegia 4:43-56.

BEDBROOK GM 1981 The care and management of spinal cord injuries. Springer Verlag, New York.

BERNSTEIN N 1967 The co-ordination and regulation of movements. Pergamon Press, pp. 104-113.

BORS E 1967 The spinal cord injury center of the veterans administration hospital, Long Beach, facts and thoughts. Paraplegia 5:126-130.

Cosbie Ross J 1967 Diversion of the urine in paraplegia. Paraplegia 4:209-216

Cosbie Ross, J, Harris P 1980 Tribute to Sir Ludwig Guttmann. Paraplegia 18:153-156.

Dollfus P 1970 The French point of view in the classification and nomenclature in paraplegia. Paraplegia 8:73-75.

FRANKEL H 1976 Book review of textbook of sport for the disabled. Paraplegia 14:241.

GuttmanN, SiR Ludwig 1963 Foreword Paraplegia 1:1.

GutTMANN, Sir LuDwig 1967 History of the spinal injuries centre. Stoke Mandeville Hospital, Aylesbury. Paraplegia 5:115-126.

GutTMANN, SiR LUDWIG 1973 Spinal cord injuries-comprehensive management and research. Blackwell Scientific Publications pp. 639-645.

Guttmann, Sir Ludwig 1980 Editorial Paraplegia 18:1.

Guttman Sir Ludwig, Munro AF, Robinson R, Walsh JJ 1963 Effect of tilting on the cardiovascular responses and plasma catecholamine levels in spinal man. Paraplegia 1:4-18.

HARRIS P 1980 Editorial. Paraplegia 18:283-284.

Harris P, Cosbie Ross J 1979 Editorial. Paraplegia 17:1.

HARDY AG 1969 In memoriam, Dr Lional Wolman. Paraplegia 7:142.

JACOBS MJ 1967 Development of motor behavior. American journal of physical medicine 46:41-51.

Jousse AT 1982 Late complications of traumatic paraplegia. Editorial. Paraplegia 20:18-19.

KERR WG, ThOMSON MA 1972 Acceptance of disability of sudden onset in paraplegia. Paraplegia 10:94-102.

LORBER J 1971 Results of treatment of myelomeningocele. Developmental Medicine and Child Neurology Supp 13:279-303.

MichAELIS LS 1969 International inquiry on neurological terminology and prognosis in paraplegia and tetraplegia. Paraplegia 7:1-9.

Pool GM 1965 Electro-myographic study of the flexion reflex of the lower limb. Paraplegia 3:188-193.

Pool GM 1971 Thoughts about the measurement of muscle tone. Paraplegia 9:73-77.

Pool GM, VAN WEERDEN GJ 1973 Experiences with frogbreathing tetraplegic polio victims as telephone operators. Paraplegia 11:253-256.

QUERIDO A 1983 Het geheim van de chirurgijns. Organorama 20:12-14.

SCRUTON JOAN 1979 Sir Ludwig Guttmann: Creator of a world sports movement for the paralysed and other disabled. Paraplegia 17:52-55. 
SHARRARD WJW 1957 The pattern of recovery in relation to walking. European Association Poliomyelitis Vol. 4 pp. 108-111.

SHARRARD WJW 1963 Spina Bifida. Paraplegia 1:190-193.

Wolman L 1964 The neuropathology of traumatic paraplegia. A critical historical review.

Paraplegia 1:233-251.

Wolman L 1966 Axon regeration after spinal cord injury. Paraplegia 4:175-184.

Wolman L 1968 Discussion on classification of neurological lesions. Paraplegi 6:49-50.

YEO JD 1967 Discussion on organisation of spinal units. Paraplegia 5:184.

YEO JD 1976 A review of experimental research in spinal cord injury. Paraplegia 14:1-11.

Young JS 1976 The United States national spinal cord injury data research center. Paraplegia 14:81-86.

Young JS, Burns PE, Bowen AM, Roberta McCutchen 1982 Spinal Cord Injury Statistics. Good Samaritan Medical Center, Phoenix Arizona. 